Gut, 1963, 4, 231

\title{
The vitamin B12 content of human liver tissue obtained by aspiration biopsy
}

\author{
R. A. JOSKE ${ }^{1}$ \\ From the Department of Medicine, University of Western Australia, and the \\ Royal Perth Hospital, Perth, Western Australia
}

EDITORIAL SYNOPSIS It is possible to estimate the vitamin B12 content of liver specimens obtained by needle biopsy. The liver B12 content is not related to the serum levels of vitamin B12, bilirubin, alkaline phosphatase, glutamic-oxaloacetic transaminase, or albumin. It is reduced in a number of pathological conditions of the liver and the reasons for this are discussed, as also are the factors determining the content of B12 in the normal liver.

Vitamin B12 (cyanocobalamin) is normally absorbed, probably by the intrinsic factor mechanism in the lower ileum. It is stored in the liver and from there transported to the bone marrow and other sites for utilization in nuclear maturation. It is excreted in the urine, and to a lesser extent, in the bile (Stokes, 1961).

Because of difficulty in obtaining human liver for analysis, studies of vitamin B12 storage and deficiency in man have perforce been made chiefly by estimation of serum B12 levels. These studies have been reviewed by Cowling and Mackay (1959) and by Smith (1960), among others.

The serum vitamin B12 level in health normally lies between 160 and $900 \mu \mu \mathrm{g}$. per ml., being low in B12 deficiency and raised following parenteral B12 therapy. In both experimental liver injury and clinical liver disease high serum B12 values are not infrequent (Stein, Stein, Aronovitch, Grossowicz, and Rachmilewitz, 1956; Cowling and Mackay, 1959). They are most often found in diffuse parenchymal cell damage and neoplastic involvement of the liver, and occasionally present in nutritional cirrhosis and active chronic hepatitis. Rarely, the rise may be extreme, as in the patient with 'obstructive hepatic necrosis' reported by Mackay, Cowling, and Gray (1957), and in some patients with metastatic carcinoma of the liver.

Several factors have been implicated in these changes, but release of stored vitamin B12 from damaged parenchymal cells appears quantitatively most important. There may also be a decrease in hepatic B12 uptake from portal blood (Glass, 1959), impaired storage of B12 by damaged liver cells, and possibly changes in the B12-binding capacity of

'Adolph Basser research fellow, Royal Australasian College of Physicians. serum, although increased $\alpha$-globulins which bind B12 (Pitney, Beard, and Van Loon 1954) are not usual in liver disease.

Direct studies of liver B12 content have not been extensive and have been made largely on necropsy material. The reported results vary slightly, depending on methods of extraction and assay of B12. Ross and Mollin (1957) and Pitney and Onesti (1961) both reported higher B12 yields when assay followed papain digestion. Swendseid, Hvolboll, Schick, and Halsted (1957) reported a mean value of $0.70 \mu \mathrm{g}$. per $\mathrm{g}$. wet liver tissue in 132 necropsy specimens, using $L$. leishmannii as test organism, while Pitney and Onesti (1961) found a mean value of $0.78 \mu \mathrm{g}$. per gram with a range from 0.61 to 1.02 $\mu \mathrm{g}$. per gram wet liver tissue. They used Euglena gracilis as test organism after preliminary papain digestion. In disease, Girdwood (1952) found negligible amounts of vitamin B12 in the liver of a patient dying with untreated pernicious anaemia. Swendseid and her colleagues (1957) reported a low mean level of $0.26 \mu \mathrm{g}$. per $\mathrm{g}$. in necropsy specimens from cirrhotic patients.

Studies of the vitamin B12 content of tissue obtained by needle biopsy of the liver have appeared in recent years. French workers (Wolff, Drouet, and Karlin-Weissman, 1951) first developed this technique, and demonstrated low liver B12 levels in pernicious anaemia with restoration towards normal following treatment with vitamin B12. In succeeding years, however, few reports dealing with this subject appeared in the literature, possibly because of doubts of the accuracy of an assay necessarily made on a small amount of fragmented tissue. This problem has been resolved by the work of Jhala and Gadgil (1960) and of Pitney and Onesti (1961). 
Both groups estimated vitamin B12 activity by modifications of the method of Ross (1952), and compared the B12 content of specimens obtained by biopsy needle with those of tissue blocks obtained at the same time at necropsy. Jhala and Gadgil (1960) found close agreement between the two in 10 of 12 instances. Their 'biopsy' weights ranged from 4.2 to $10 \mathrm{mg}$. Discordant results occurred with weights of 5 and $7 \mathrm{mg}$. Pitney and Onesti (1961), in a more extensive investigation of both normal and cirrhotic livers, found that tissue blocks from either lobe had a similar B12 content, and that the assay of the biopsy agreed with assay of the block to within $20 \%$, provided the biopsy weight was at least $7 \mathrm{mg}$. With lesser biopsy weights there were larger discrepancies. It is probable, therefore, that assay of liver biopsy specimens gives a satisfactory estimation of liver B12 content.

The only extensive investigations of liver B12 content using liver biopsy have been those of Nelson and Doctor $(1958,1960,1962)$. They used L. leishmannii as test organism without preliminary papain digestion, but reported a higher normal range, from 1.41 to 2.58 (mean 1.94 ) $\mu \mathrm{g}$. per $\mathrm{g}$. wet liver tissue. Values were low in cirrhosis, fatty liver, obstructive jaundice, and viral hepatitis. In neoplastic disease results varied, the liver B12 content being lowest in specimens containing metastatic tumours. They also noted elevations of serum B12 levels in all types of malignant neoplasm, the mechanism of which was uncertain.

The present paper is an extension of these results, especially of those of Pitney and Onesti (1961), and reports changes in liver B12 content of biopsy specimens in relation to clinical, histological, and biochemical changes in 68 patients with various diseases.

\section{PATIENTS STUDIED AND LABORATORY METHODS}

Liver tissue for bio-assay was obtained on 70 occasions from 68 patients, comprising 44 males and 24 females. Their ages ranged from 19 to 81 years with a mean of 54 years. The majority (49) were between 40 and 70 years of age. All were of Caucasian stock except four Australian aboriginals and three of mixed race. None had received vitamin $B 12$ parenterally before biopsy. The indications for liver biopsy were the differential diagnosis of jaundice, hepatomegaly, or disseminated granulomatous disease. The wet weight of liver tissue available for assay ranged from 7.0 to $28.7 \mathrm{mg}$. with a mean of $12.6 \mathrm{mg}$.

Vitamin B12 assay was performed after papain digestion using the $\mathrm{Z}$ strain of Euglena gracilis (Pitney and Onesti, 1961). The normal values for this method lie between 0.61 and $1.02 \mu \mathrm{g}$. per g. wet liver tissue. Serum B12 estimations followed the method of Ross (1952), the normal range for this laboratory being from 160 to 900 $\mu \mu \mathrm{g}$. per ml. (Nicholas and Pitney, 1958). Histological and biochemical estimations were performed by standard methods.

\section{RESULTS}

Allowing for differences in diagnosis, the results were not affected by the age or sex of the patient, or the month of the year in which biopsy was performed. Biopsies from aboriginal patients were too few to allow assessment of possible racial factors. The mean B12 content of biopsies from female patients was slightly lower than that of biopsies from male patients, $0.48 \mu \mathrm{g}$. per g., compared with $0.59 \mu \mathrm{g}$. per g., but the difference was of doubtful statistical significance $(0.1>p>0.05)$.

The relation between histological diagnosis and liver B12 content is summarized in Table $I$, and individual results in each group are shown in detail in Figure 1.

\section{TABLE I}

VITAMIN B12 CONTENT OF LIVER BIOPSY SPECIMENS IN RELATION TO HISTOLOGICAL DIAGNOSIS

\begin{tabular}{|c|c|c|c|}
\hline \multirow[t]{2}{*}{ Histological Diagnosis } & \multirow{2}{*}{$\begin{array}{l}\text { No. of } \\
\text { Cases }\end{array}$} & \multicolumn{2}{|c|}{ B12 Content ( $\mu \mathrm{g} . / \mathrm{g})}$. \\
\hline & & Mean & Range \\
\hline Normal histology & 9 & 0.87 & $0 \cdot 39-1 \cdot 33$ \\
\hline Fatty change & 12 & 0.47 & $0 \cdot 19-0.93$ \\
\hline Parenchymal cell damage & 10 & 0.64 & $0.25-0.93$ \\
\hline Metastatic neoplasm & 9 & 0.47 & $0 \cdot 20-0 \cdot 75$ \\
\hline Portal cirrhosis & 7 & 0.43 & $0 \cdot 19-0.89$ \\
\hline Cholestatic jaundice & 7 & 0.55 & $0 \cdot 26-1 \cdot 17$ \\
\hline Viral hepatitis & 5 & 0.57 & $0 \cdot 29-1 \cdot 11$ \\
\hline Haemochromatosis & 5 & 0.49 & $0 \cdot 18-0 \cdot 73$ \\
\hline External biliary obstruction & 4 & 0.25 & $0 \cdot 16-0 \cdot 45$ \\
\hline Dubin-Johnson syndrome & 1 & 0.92 & - \\
\hline Multiple granulomata & $i$ & 0.72 & - \\
\hline
\end{tabular}

The biopsy was histologically normal in 12 cases, but in three later examination disclosed extensive metastatic carcinoma in the liver and these have, therefore, been excluded. The mean and range of the other nine specimens agree closely with those of Pitney and Onesti (1961), providing further evidence of the validity of bio-assay of small specimens. There was only one low result, $0.39 \mu \mathrm{g}$. per $\mathrm{g}$. in a man of 48 years with megaloblastic anaemia due to nutritional folic acid deficiency. Since his serum B12 was at the lower normal limit, $160 \mu \mu \mathrm{g}$. per ml., it is probable that his diet was also deficient in vitamin B12.

In 12 biopsies the chief histological change was fatty metamorphosis, and the B12 content was below normal in 10 of these with a mean of $0.47 \mu \mathrm{g}$. per $\mathrm{g}$. In eight of the 12 cases the fatty change was associated with alcoholism and the mean B12 content of these with $0.39 \mu \mathrm{g}$. per $\mathrm{g}$. It is possible that two factors are involved, replacement of parenchymal tissue by lipid and inadequate B12 intake due to malnutrition in chronic alcoholics.

Ten biopsies showed only slight to moderate nonspecific parenchymal cell damage without gross 


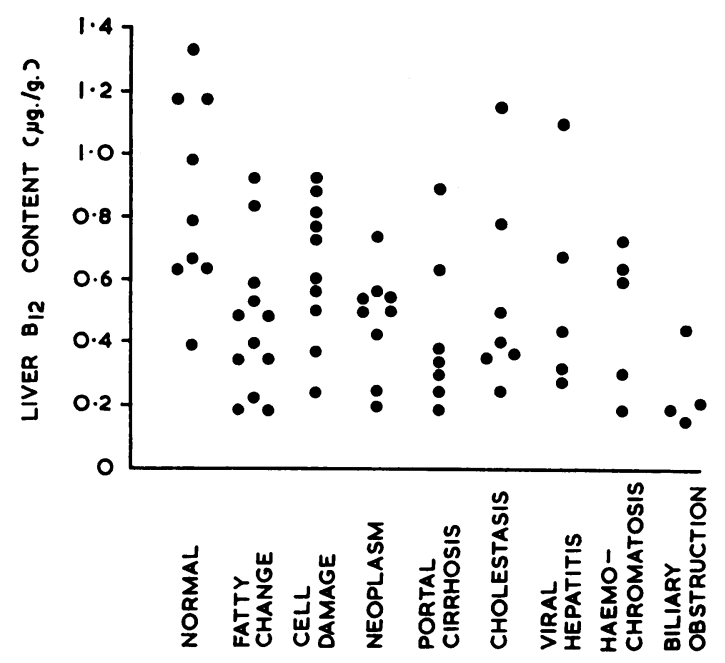

FIG. 1. Scattergram showing B12 content of liver biopsy specimens in relation to histological diagnosis.

fatty change. The mean B12 content of these was $0.63 \mu \mathrm{g}$. per $\mathrm{g}$. This group included two biopsies from a patient with megaloblastic anaemia complicating anticonvulsant therapy with B12 contents of 0.25 and $0.38 \mu \mathrm{g}$. per $\mathrm{g}$. However, this syndrome is probably associated with nutritional deficiency in the majority of cases (Stokes and Fortune, 1958). The remaining eight specimens had a mean B12 content of $0.73 \mu \mathrm{g}$. per g., with a range from 0.50 to $0.93 \mu$ g. per g., which does not differ greatly from the normal values.

The nine biopsies grouped as metastatic neoplasm include six in which this was demonstrated in the biopsy specimen and three in which it was shown subsequently. The primary site was in the pancreas or gut in seven cases and in the lung in one, the final patient having disseminated reticulosarcoma. Low B12 contents were frequent, the mean of the group being $0.47 \mu \mathrm{g}$. per $\mathrm{g}$. It is of interest that all three histologically normal specimens had a low B12 content.

The B12 content was below normal in five of seven patients with portal cirrhosis, the mean of the group being $0.43 \mu \mathrm{g}$. per $\mathrm{g}$. Six of the seven were alcoholics while the remaining patient suffered from diabetes mellitus and had a liver B12 content of $0.89 \mu \mathrm{g}$. per $\mathrm{g}$. If this patient is excluded, the mean of the other six was $0.35 \mu \mathrm{g}$. per $\mathrm{g}$. By contrast, the results in haemochromatosis were slightly higher, the mean of five patients, two of whom were overt diabetics, being $0.49 \mu \mathrm{g}$. per $\mathrm{g}$.

The low mean B12 content of biopsies from patients with cholestatic jaundice was largely due to four patients with chlorpromazine jaundice. The highest B12 content from these patients was $0.41 \mu \mathrm{g}$. per g. and the mean was $0.35 \mu \mathrm{g}$. per g. Cholestasis from other causes had little effect upon liver B12 content.

The low results in patients with viral hepatitis and external biliary obstruction are discussed further below.

Although the relation between clinical diagnosis and liver B12 content has largely been discussed in the preceding paragraphs, in three instances a single clinical condition was associated with a variable histological picture. These were chronic alcoholism, diabetes mellitus, and folic acid deficiency. Liver B12 content was below $0.60 \mu \mathrm{g}$. per g. in 13 of 20 biopsies from chronic alcoholics, the mean of the whole group being $0.45 \mu \mathrm{g}$. per $\mathrm{g}$. The low results were found in specimens which histologically showed fatty change or portal cirrhosis. On the other hand, six of seven patients with diabetes mellitus had liver B12 contents within the normal range, the mean value being $0.77 \mu \mathrm{g}$. per g. Only one of these biopsies was histologically normal. The low result, $0.31 \mu \mathrm{g}$. per g., occurred in a severe alcoholic with haemochromatosis.

Four biopsies were obtained from three patients with megaloblastic anaemia due to folic acid deficiency. The B12 content was low in all, the highest value being $0.39 \mu \mathrm{g}$. per $\mathrm{g}$. and the mean $0.30 \mu \mathrm{g}$. per $\mathrm{g}$.

There was little relation between liver B12 content and serum biochemical values.

The serum bilirubin at the time of biopsy was greater than $1.0 \mathrm{mg}$. per $100 \mathrm{ml}$. in 38 of the 70 cases. Although patients with biliary obstruction, cholestasis, or viral hepatitis had high bilirubin levels and low liver B12 contents, there was in general no relation between the two.

The serum glutamic-oxaloacetic transaminase was measured in 49 instances, and the serum albumin in 65 instances. Neither was significantly related to liver B12 content.

The serum alkaline phosphatase was measured in 67 of the 70 cases. In both cholestasis and external biliary obstruction, the serum alkaline phosphatase was raised and the liver B12 content lowered. Thus, 11 of 13 cases with phosphatase levels above 30 King-Armstrong units had liver B12 contents below the normal range, and all of 13 with liver B12 contents greater than $80 \mu \mathrm{g}$. per g. had serum alkaline phosphatase levels below $20 \mathrm{King}$-Armstrong units.

The serum B12 levels were estimated at the time of biopsy in 60 of the 70 cases, and corresponding serum and liver B12 levels in these are shown in Table II. No patient had a serum B12 content below the normal lower limit of $160 \mu \mu \mathrm{g}$. per ml. Slight elevation of serum B12 $(>1,000 \mu \mu \mathrm{g}$. per ml.) 
TABLE II

SERUM AND LIVER B12 CONTENTS IN RELATION TO HISTOLOGICAL DIAGNOSIS ${ }^{1}$

\begin{tabular}{|c|c|c|c|c|c|}
\hline \multirow[t]{2}{*}{ Diagnostic Group } & \multirow[t]{2}{*}{ No. of Cases } & \multicolumn{2}{|c|}{ Serum B12 ( $\mu \mu \mathrm{g} . / \mathrm{ml})}$. & \multicolumn{2}{|c|}{ Liver B12 ( $\mathrm{gg} . / \mathrm{g})}$. \\
\hline & & Mean & Range & Mean & Range \\
\hline Normal histology & 7 & 430 & $160-1,060$ & 0.91 & $0 \cdot 39-1 \cdot 33$ \\
\hline Fatty change & 12 & 475 & $220-770$ & 0.47 & $0 \cdot 19-0.93$ \\
\hline Parenchymal cell damage & 9 & 630 & $260-1,840$ & 0.65 & $0.25-0.93$ \\
\hline Metastatic neoplasm & 7 & 5,980 & $450-20,400$ & 0.51 & $0.25-0.75$ \\
\hline Portal cirrhosis & 7 & 900 & $330-1,990$ & 0.43 & $0 \cdot 19-0 \cdot 89$ \\
\hline Cholestatic jaundice & 7 & 600 & $290-980$ & 0.55 & $0 \cdot 26-1 \cdot 17$ \\
\hline Viral hepatitis & 3 & 1,240 & $700-1,920$ & 0.57 & $0 \cdot 29-1 \cdot 11$ \\
\hline Haemochromatosis & 5 & 870 & $370-1,410$ & 0.49 & $0 \cdot 18-0 \cdot 73$ \\
\hline External biliary obstruction & 3 & 1,100 & $510-1,940$ & 0.27 & $0 \cdot 16-0.45$ \\
\hline
\end{tabular}

'The results differ slightly from those in Table I because the serum B12 was not estimated in all cases.

occurred in 10 cases, two each of portal cirrhosis, viral hepatitis, and haemochromatosis, and one each of external biliary obstruction, parenchymal cell damage, metastatic carcinoma, and with normal histology. Extreme elevation was found in two patients with hepatic metastases from carcinoma of the pancreas with serum B12 levels of 20,400 and $17,900 \mu \mu$ g. per ml. respectively.

No correlation was apparent between serum B12 levels and liver B12 contents. This may be due to the fact that, although B12 deficiency results in low levels in both serum and liver, liver damage may deplete liver B12 stores while increasing serum B12 levels. An attempt was made to compare the various diagnostic groups with each other by calculating for each patient the ratio of serum to liver B12. With the present units this ratio normally lies below 1,500. It is increased if the serum $B 12$ is increased or the liver B12 is reduced, or both. In the patients with normal liver histology this ratio was within the normal range in all except one in whom it was 15,800 due to a high serum B12 level. The ratio was above normal in all patients with viral hepatitis or external biliary obstruction, but in other groups was extremely variable. The results do not suggest that this ratio would be of value in the differential diagnosis of liver disease.

\section{DISCUSSION}

The major theoretical difficulties in the use of liver biopsy specimens for bio-assay are the sampling error inherent in using small amounts of tissue, and the reference standard to which the results are referred.

The first of these is the more serious, and it is probable that in patients where liver disease is not diffuse, such as cirrhosis or metastatic neoplasm, occasional anomalous results will be due to this inherent sampling error. The scattering of results in the present series (Fig. 1) may be in part a reflection of this difficulty. There is, however, evidence to suggest that the variation may be smaller than would first appear. Pitney and Onesti (1961) found agreement between B12 contents of 'biopsy' specimens and tissue blocks in cirrhotic as well as in normal livers. In addition, results within each of the published series are consistent, and, as will be discussed below, the various series agree well with each other.

The problem of a reference standard to which B12 contents may be referred is related to this problem of possible sampling error. Previous workers without exception have used the wet weight of liver as a reference unit, and the present paper follows this convention. This is both for convenience in comparing results of different workers, and because although more sophisticated standards such as the content of D.N.A. have been suggested, they are unfortunately open to similar objections in non-diffuse liver disease as have been discussed above.

Within these limits, the present results may be compared with others reported in the literature. The mean and range of histologically normal specimens are close to those of Swendseid et al. (1957) and of Pitney and Onesti (1961) determined on necropsy material. They are somewhat higher than those of Drouet, Wolff, Karlin-Weissman, and Rauber (1951) and Jhala and Gadgil (1960). It is possible that the latter, in India, were dealing with patients whose nutrition was suboptimal. Nelson and Doctor (1958) reported rather higher values from control patients, the mean from 12 subject being $1.94 \mu \mathrm{g}$. per g., with a range from 1.41 to $2.58 \mu \mathrm{g}$. per $\mathrm{g}$. The difference may be due to different methods of extraction and assay.

In patients with liver disease, the present mean liver B12 content for patients with portal cirrhosis, $0.43 \mu \mathrm{g}$. per g., agrees reasonably with the figure of $0.26 \mu$ g. per g. reported by Swendseid and her colleagues (1957). In abnormal subjects Nelson and Doctor $(1960,1962)$ again found liver B12 levels higher than in the present series, but agree in finding low levels in specimens showing cirrhosis, fatty change, cholestasis, obstructive jaundice, and viral hepatitis. Those with fatty change (with or without cirrhosis) and viral hepatitis gave the lowest values. 
The combined results of these various investigations allow some general conclusions to be drawn regarding the factors responsible for liver B12 content. Deficiency of vitamin B12 from any cause lowers hepatic B12 stores. This may occur in pernicious anaemia (Drouet et al., 1951), and to a lesser extent in other states of malnutrition, such as alcoholism, since the results in nutritional cirrhosis were lower than those in haemochromatosis. The low liver B12 content in folic acid deficiency is of interest; it may be nutritional in origin, or, more likely, reflect increased tissue demands for vitamin B12 in the presence of subnormal folic acid supply.

Damage to parenchymal cells seems the most probable cause of the low liver B12 levels usual in viral hepatitis, since the serum B12 is often increased in the condition. The lack of correlation between lower liver B12 contents and increased serum glutamic-oxaloacetic transaminase levels does not conflict with this, since glutamic-oxaloacetic transaminase is cleared from plasma rapidly (Dunn, Martins, and Reissmann, 1958) compared with B12. The raised serum B12 level in some patients with cirrhosis probably also reflects continuing parenchymal cell damage. Nelson and Doctor (1960) suggest that, in addition, hepatic capacity to store B12 may be diminished.

The cause of the low liver B12 content in patients with external biliary obstruction is less certain. It is not an artefact due to the presence of bile components in large amounts in the specimen, for higher levels occur in the cholestatic syndrome, especially when due to causes other than chlorpromazine. Parenchymal cell damage and diminished storage capacity seem likely explanations, but further studies are required for a definite answer.

Replacement of parenchymal cells by tissue unable to store vitamin B12 is also important. This applies to fibrous tissue in cirrhosis, to fatty change in the liver (where malnutrition may also be a factor), and to metastatic neoplasm, where the capacity of the neoplastic cells to store B12 is less than that of normal parenchymal cells (Nelson and Doctor, 1962). There are, however, several anomalous findings in this situation. Parenchymal tissue without histological neoplastic infiltration has been found in some instances to have a low B12 content (Nelson and Doctor, 1958; present series). Moreover, there are reports of raised serum B12 levels, often extreme, in patients with various types of neoplasm irrespective of whether the liver is directly involved (Beard, Pitney, and Sanneman, 1954; Grossowicz, Hochman, Aronovitch, Izak, and Rachmilewitz, 1957; Nelson and Doctor, 1962, present series). Other patients with apparently comparable disease show normal or low serum B12 levels. No explanation of these anomalies has been suggested, and metabolism of vitamin B12 in patients with neoplastic disease remains an unsolved problem.

My thanks are due to Dr. W. R. Pitney from whose studies this project was developed, and to my colleagues in the Departments of Haematology and Biochemistry, Royal Perth Hospital, for observations reported in this paper.

\section{REFERENCES}

Beard, M. F., Pitney, W. R., and Sanneman, E. H. Jr. (1954). Serum concentrations of vitamin B12 in patients suffering from leukemia. Blood, 9, 789-794.

Cowling, D. C., and Mackay, I. R. (1959). Serum vitamin B12 levels in liver disease. Med. J. Aust., 46,(2), 558-562.

Drouet, P. L., Wolf, R., Karlin-Weissman, R., and Rauber, G. (1951). Etude de la vitamine B12 hépatique par la ponctionbiopsie. Premiers résultats dans la maladie de Biermer. Bull. Soc. méd. Hôp. Paris, 67, 281-286.

Dunn, M., Martins, J., and Reissmann, K. R. (1958). The disappearance rate of glutamic oxalacetic transaminase from the circulation and its distribution in the body's fluid compartments and secretions. J. Lab. clin. Med., 51, 259-265.

Girdwood, R. H. (1952). The occurrence of growth factors for Lactobacillus leichmannii, Streptococcus faecalis and Leuconostoc citrovorum in the tissues of pernicious anaemia patients and controls. Biochem. $J_{\text {., 52, 58-63. }}$

Glass, G. B. J. (1959). Deposition and storage of vitamin B12 in the normal and diseased liver. Gastroenterology 36, 180-192.

Grossowicz, N., Hochman, A., Aronovitch, J., Izak, G., and Rachmilewitz, M. (1957). Malignant growth in the liver and serum-vitamin-B12 levels. Lancet, 1, 1116-1117.

Jhala, C. I., and Gadgil, R. K. (1960). Estimation of vitamin B12 content of human liver by biopsy needle. J.J.J. Hosp. Grant med. Coll., 5, 36-38.

Mackay, I. R., Cowling, D. C., and Gray, A. (1957). Highly raised serum vitamin B12 levels in "obstructive hepatic necrosis". Brit. med. J., 2, 800-801.

Nelson, R. S., and Doctor, V. M. (1958). The vitamin B12 content of human liver as determined by bio-assay of needle biopsy material. Ann. intern. Med., 49, 1361-1367.

- (1960). Hepatic and serum vitamin B12 content in liver disease. Gastroenterology, 38, 188-193.

- (1962). Vitamin B12 content of liver and serum in malignant neoplasia. Ibid., 42, 414-418.

Nicholas, D. R., and Pitney, W. R. (1958). Microbiological assay of vitamin B12 content of serum using Euglena gracilis. Aust. J. exp. Biol. med. Sci., 36, 603-608.

Pitney, W. R., Beard, M. F., and Van Loon, E. J. (1954). Observations on the bound form of vitamin B12 in human serum. J. biol. Chem., 207, 143-152.

_, and Onesti, P. (1961). Vitamin B12 and folic acid concentrations of human liver with reference to the assay of needle biopsy material. Aust. J. exp. Biol. med. Sci., 39, 1-7.

Ross, G. I. M. (1952). Vitamin B12 assay in body fluids using Euglena gracilis. J. clin. Path., 5, 250-256.

- and Mollin, D. L. (1957). In Vitamin B12 and Intrinsic Factor, edited by H. C. Heinrich, p. 437. Cited by Pitney and Onesti, Enke, Stuttgart.

Smith, E. L. (1960). Vitamin B12. Methuen, London.

Stein, Y., Stein, O., Aronovitch, J., Grossowicz, N., and Rachmilewitz, M. (1956). Serum vitamin B12 in experimental liver injury. Bull. Res. Coun. Israel, E6, 5.

Stokes, J. B. (1961). Metabolites of vitamin B12 in bile after parenteral administration of the vitamin. Nature (Lond.), 191, 807-808. and Fortune, C. (1958). Megaloblastic anaemia associated with anticonvulsant drug therapy. Aust. Ann. Med., 7, 118-125.

Swendseid, M. E., Hvolboll, E., Schick, G., and Halsted, J. A. (1957). The vitamin B 12 content of human liver tissue and its nutritional significance. A comparison study of various age groups. Blood, 12, 24-28.

Wolff, R., Drouet, P. L., and Karlin-Weissman, R. (1951). L'emploi de la ponction-biopsie pour l'étude de la vitamine B12 hépatique chez l'homme. C. R. Acad. Sci. (Paris), 232, 568-569. 